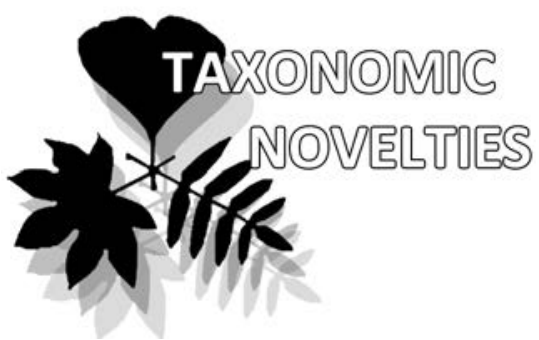

\title{
Notes on Salvia baldshuanica (Lamiaceae), an endemic species from Middle Asia
}

\author{
Obidjon A. Turdiboev ${ }^{1}$, Elena V. Baikova ${ }^{2 *}$, Feruz Akbarov ${ }^{1} \&$ \\ Konstantin S. Baikov ${ }^{2}$
}

Obidjon A. Turdiboev ${ }^{1}$

e-mail: turdiboyev.obidjon@mail.ru

Elena V. Baikova2*

e-mail: elenabaikova@mail.ru

Feruz Akbarov ${ }^{1}$

e-mail: feruz.akbar@mail.ru

Konstantin S. Baikov²

e-mail: kbaikov2018@mail.ru

${ }^{1}$ Institute of Botany, Academy of Sciences of the Republic of Uzbekistan, Tashkent, Uzbekistan

${ }^{2}$ Central Siberian Botanical Garden SB RAS, Novosibirsk, Russia

\section{* corresponding author}

Manuscript received: 08.06.2021 Review completed: 30.09.2021

Accepted for publication: 12.10.2021

Published online: 14.09.2021

\begin{abstract}
A B S T R A C T
We present a critical revision of information about rare and endangered endemic species Salvia baldshuanica (Lamiaceae), included in the Red Books of the USSR and Tajikistan. As the nomenclatural type had been missing, we assembled information on the original herbarium material performed a proper typification of the species name. A chorological analysis of the species distribution in Middle Asia was carried out. To assess the state of the current natural populations, a topographic mapping of localities (Sanglok mountains, two isolated local populations; Sarsaryak ridge, one local population) was made. A narrow edaphic confinement of plants of this species to gypsum-bearing mountain soils has been established. A taxonomic assessment of the key morphological traits of $S$. baldshuanica confirmed at least the sectional level of its position within the subgenus Leonia. The species was found in nature only three times - in 1883, 1937 and 1979, which confirms its exceptional rarity and high scientific interest.
\end{abstract}

Keywords: chorology, endangered species, morphology, nomenclature, typification

\section{P E 3 Ю M E}

Тураибоев О.А., Байкова Е.В., Акбаров Ф., Байков К.С. Заметки о Salvia baldshuanica (Lamiaceae), эндемичном виАе из Средней Азии. Проведена критическая ревизия сведений о редком и исчезающем эндемичном виле Salvia baldshuanica (Lamiaceae), внесенном в Красные книги СССР и Таджикистана. В связи с отсутствием номенклатурного типа опреАелен состав оригинацьного гербарного материала и выполнена типификация названия вила. Выполнен хорологический анализ распространения вида в Средней Азии. Аیя контроця за состоянием природных популяций проведена топографическая привязка Аокалитетов (горы Санглок, Аве изомированные мокальные популяции; хребет Сарсаряк, одна Аокальная попуАяция). Установлена узкая эдафическая приуроченность растений Аанного вида к гипсоносным горным породам. Таксономическая оценка ключевых морфологических признаков $S$. baldshuanica подтведила как минимум секционный уровень его обособленности в пределах подрода Leonia. Вид был найден в природе всего трижды - в 1883, 1937 и 1979 годах, что подтвержАает его искАючительную редкость и высокий научный интерес.

КАючевые слова: хорология, исчезающие виды, морфология, номенклатура, типификация
Endemic species have a high conservation priority, as they are exclusive to a geographically restricted and limited territory. Being often rare and ecologically infrequent, any unfavorable change can cause their rapid extinction (Callmander et al. 2008). The study of endemic species of Middle Asia is carried out within the framework of long-term international cooperation of the Central Siberian Botanical Garden SB RAS with research institutes of Uzbekistan and Tajikistan. Significant results have been obtained on morphology, distribution and nomenclature (Davlatov \& Baikova 2011, Ovchinnikova et al. 2020), especially of representatives of the Lamiaceae family (Bobokalonov et al. 2020, Cheryomushkina et al. 2020, Talovskaya 2020).

Genus Salvia L., the largest in the Lamiaceae family, is represented in Middle Asia by 35 species (Khassanov et al. 2015); 20 of them are endemic to this region (Makhmedov 1984). An extremely rare Middle Asiatic local endemic species is Salvia baldshuanica Lipsky. According to Makhmedov
(1984), its range is extremely limited. Data on S. baldshuanica in GBIF (2021), POWO (2021), COL (2021) databases are scarse, its specimens are absent in JSTOR (2021) and Virtual Herbaria (2021). The species is included in the Red Data Books of the USSR (Borodin et al. 1984) and Tajikistan (Rahimi et al. 2017) in a critical status because it is completely inactive; urgent special protection of the species is required. It is therefore necessary to identify the modern range of the species. The results will target future conservation action for this endangered species and improve our understanding of plant extinctions. The latter ones are a significant part of the global problem of the world's biodiversity extinction (Humphreys et al. 2019).

Salvia baldshuanica is characterized by a unique set of features of the flower, which are diagnostic traits of a high taxonomic rank. Pobedimova (1954) in the revision of Salvia in the "Flora of the USSR" described the new monotypic subgenus Sanglakia Pobed. including S. baldshuanica, and 
showing its separate position in the genus. Makhmedov (1980) assigned this species to the monotypic section Sanglakia (Pobed.) Machmedov, which he considered as part of the subgenus Leonia (Llav. et Lex.) Benth. The morphological diagnosis of the species was given in Latin and Russian when describing the species by Lipsky (1900). It was subsequently expanded and detailed by Pobedimova (1. c.). Now it is necessary to modify the description of S. baldshuanica on the basis of modern morphological approaches and terminology, taking into account the type of synflorescence and the division of shoots into structural and functional zones.

Salvia baldshuanica was first described by V. Lipsky (1900) based on herbarium specimens collected by A. Regel in 1883 from the eastern slope of the Sanglok Mountain range. There is no information on type specimens in the protologue of the species, so typification is necessary in such a case.

The targets of this work are to identify the current range and clarify the morphological features of S. baldshuanica, a rare and endangered endemic species of Middle Asia, as well as typification of the species name.

\section{MATERIAL AND METHODS}

In order to prepare a full description for $S$. baldshuanica, we collected plant material from the geographical distribution range of the species in Tajikistan during 1979. Three authentic specimens tested by Lipsky as a new species S. baldshuanica (original materials), which are deposited in LE (herbarium acronyms hereafter in accordance to B. Thiers, 2016) as well as all other specimens of the species stored in LE, Middle Asia Sector and General Sector were studied in detail. In addition, we examined specimens stored in TAD, TASH, US. Herbarium samples from P and US were studied from images freely available on the Internet. Lectotype and isolectotype are designated below in accordance with Article 9 of the Shenzhen Code (Turland et al. 2018). Label texts for all specimens are provided in full, with barcodes where these have been assigned. The protologue, herbarium specimens of $S$. baldshuanica and information from international nomenclatural and taxonomic electronic plant databases (IPNI 2021, WCVP 2021, POWO 2021, WCSP 2021, COL 2021) were analyzed during this research.

\section{RESULTS}

Salvia baldshuanica Lipsky 1900, Trudy Imp. S.-Peterburgsk. Bot. Sada 18:89.

Locus classicus: "Бальджуанъ: вост. склонъ горы Сенгулакъ на р. Вахшъ 5.000', 13 мая 1883 (А. Регемь !) [Balzhuan: eastern slope of Sengulak Mt. in the Vakhsh River Basin 5.000', 13 May 1883 (A. Regel !)]" (Lipsky 1900: 91).

Typification of the species name. Original material and type specimens were chosen and designated here. We consider as type specimens only three authentic ones tested by V.I. Lipsky as Salvia baldshuanica.

Lectotype, designated here: A. Regel, Iter Turkestanicum. Distr. Baldschuan: in duliv. orient. montis Sangulak, ad fl. Wachsch. 5000' 13-25/VII 1883 (LE, barcode LE00052480!) (Fig. 1). The lectotype for the species name was chosen among the original material as the most informative specimen in the best condition of storage. We believe that the date specified in the protologue is incorrect. According to Lipsky (1905), Regel collected plants at the Sanglok (Sangulak) Mountains on July 13, and on May 13 he did not work there. The dates in Lipsky's work are indicated according to the Julian calendar, and on the labels of the Regel herbarium they are given according to the Julian and Gregorian calendars, which is noted by Lipsky (l. c.).

Isolectotype, designated here: A. Regel, Iter Turkestanicum. Distr. Baldschuan: in duliv. orient. montis Sangulak ad ff. Wachsch 5000' 13-25/VII 1883 (LE, barcode LE00052815!).

Syntype, designated here: A. Regel, Iter Turkestanicum. In duliv. orient. montis Sangulak 5000' 13-25/VII 1883 Distr. Baldschuan (LE, barcode LE00052816!).

Other specimens examined: A. Regel, Iter Turkestanicum. In duliv. orient. montis Sangulak 5000' 13-25/VII 1883 (LE, barcode LE00052817!); A. Regel, Iter Turkestanicum. Baldshuan 1883 (LE!, two specimens without barcodes); A. Regel, Iter 'Turkestanicum. In duliv. orient. mont. Sangulak. 5000'. 13-25/ VII 83 (TAD!); P, barcode P02871887! image of the specimen is available at http://coldb.mnhn.fr/catalognumber/mnhn/p/ p02871887; US barcode US02805923! image of the specimen is available at http://n2t.net/ark:/65665/m3f2f42d61-c7b4454c-b886-ее33a906073e); Таджикистан. Юго-запад. склон хребта Сар-Саряк. 10 км. вверх от к-ка Санг-Туда по мев. берег р. Вахш. На гипсах. 29.V.1979, № 463, Камелин Р.В., Махмедов A.M. [Tajikistan. Southwest. The slope of the Sarsaryak ridge. $10 \mathrm{~km}$ upstream from the village of Sang-Tuda, on the left bank of the Vakhsh River. On gypsum rocks. 29.V.1979, No. 463, Kamelin R.V., Makhmedov A.M.] (TAD!, LE!, TASH!); Южный Таджикистан. Хребет Санглок. На гипсах близ к-ка Мансев. 9/VI.1937. М. Пряхин [Southern Tajikistan. Sanglok Ridge. On gypsum rocks near the village of Mantsev. 9/VI.1937. M. Pryakhin] (TAD!, №№ 53548, 53549).

Morphological description. Dwarf semishrub, 8-30 cm high, with a thick woody dark-brown contractile root and dark-brown thin woody perennial bases of shoots (branches of caudex). Stems ascending, annual flowering branches grayish-green, densely covered with short protrudent hairs. Leaves ovate or elliptical, obtuse or subacute, cuneate at base, decurrent, flexuous-hairy at margin, curly, doubly dentate, strongly rugose on both sides, gray, with numerous short protrudent hairs (Fig. 2). Leave blade 8-12 $\mathrm{mm}$ long, 5-7 $\mathrm{mm}$ broad, petiole as long as or shorter than blade; upper leaves subsessile. Leaves on the main axis of inflorescence (floral leaves) ovate, acute, 4-5 $\mathrm{mm}$ long, $2 \mathrm{~mm}$ broad, sessile, with dense long hairs. Inflorescence is simple racemiform thyrsus, as long as or longer than subfloral part of the stem, with distant pairs of cymes reduced to single flowers. Pedicels long-hairy, 3-6.5 $\mathrm{mm}$ long, with 2 narrowly oblong long-haired bracts. As we showed earlier (Baikova 2006), such pedicels are composite axes formed as a result of the dichazium reduction. Calyx campanulate, 9-10 mm long, long-haired outside, with short appressed hairs inside; upper lip rounded, with 3 small approximate teeth at apex, the middle tooth somewhat shorter than the lateral; lower lip bilabiate, with longer teeth; all teeth subulately short-pointed. Calyx not expanded after flowering, it easily falls off when nutlets ripen. Corolla twice as long as calyx, the tube slightly exserted, the hairy ring forming a regular circle; upper lip short, deeply bi-lobed, with obtuse elliptical lobes; lower lip three-lobed, with the lateral lobes almost equal to the 


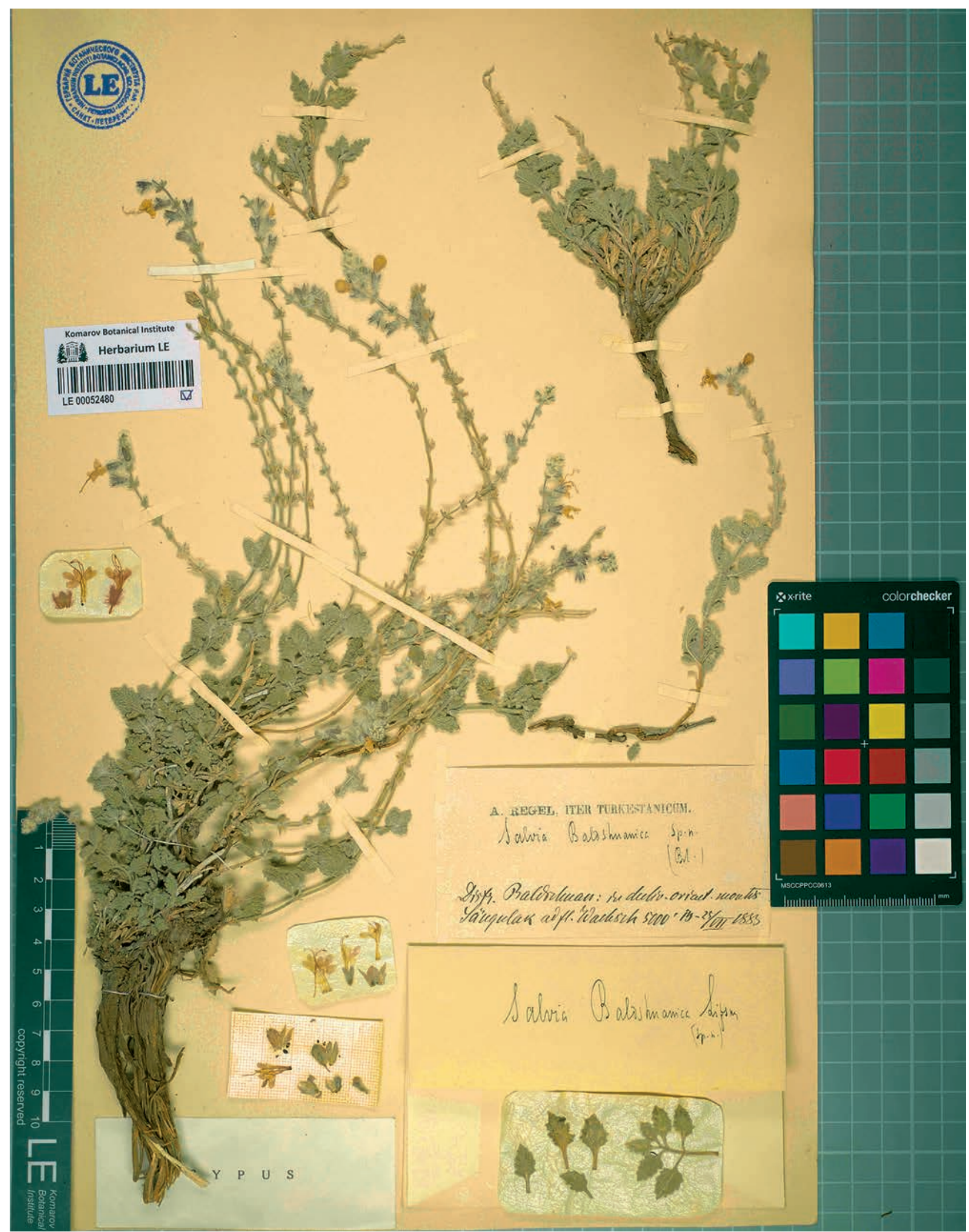

Figure 1 Lectotype of Salvia baldshuanica Lipsky (designated here). A scanned copy was kindly provided by Mariya Sheludyakova (Herbarium of the Komarov Botanical Institute, LE, Saint-Petersburg, Russia)

middle one, slightly deflected. Only lower stamens fertile; upper stamens staminodial. Staminal filaments as long as or longer than connectives which excerted outside the corolla. Connective joins the filament without visible articulation and seems to be its continuation; lower thecae absent; lower connective arm short, sterile, directed downwards along the filament (Fig. 2.6). Nutlets ellipsoid, $1.5 \mathrm{~mm}$ long, black, smooth, with oblong areola. 
The taxonomic rank of the key morphological features of S. baldshuanica (a significant reduction of the lower connective arm, joint of the connective with the filament without visible articulation, etc.) corresponds, at least to the sectional level within the subgenus Leonia. The extreme degree of lower connective arm reduction is characteristic for several independent groups of Salvia (sect. Hemisphace Benth., sect. Sanglakia, sect. Vernalia Kudo, subgen. Allagospadonopsis Briq., subgen. Audibertia J.B. Walker, B.T. Drew \& Sytsma), which are considered by taxonomists either as sections within the subgenus Leonia, or as independent subgenera or even genera. We believe that the rank of the section for such taxa is more correct (Baikova 2006), and in this case our opinion of the taxonomic status of $S$. baldshuanica corresponds to the viewpoint of Makhmedov $(1980,1984)$.

Distribution. There are three records for $S$. baldshuanica in GBIF (https://www.gbif.org/species/3884131). Two of them are based on herbarium specimens collected by Regel in 1883 (from P \& US) (MNHN \& Chagnoux 2021, Orrell \& Informatics Office 2021). These records are published without coordinates, only including information on the region of location: Tajikistan (first record in the list), and Uzbekistan (second record). The third record is based on herbarium specimen stored in MW (Seregin 2021) and labelled without coordinates, location, locality and date. Uzbekistan as location of $S$. baldshuanica was indicated in GBIF after the specimen from US. This is based on the label record "Turkestan. Baldschuan", the specified territory was mistakenly attributed to Uzbekistan instead of Tajikistan. Incorrect location information is reproduced in COL, WCSP and POWO databases. In the latter one, the map is generated (http://powo.science.kew.org/taxon/455735-1) based on the above-mentioned incorrect location information. In addition, the distribution is marked by filling the entire territory of the regions, so the range of the species has been unnecessarily expanded. Thus, we have excluded the territory of Uzbekistan from the range of the species and estimate such records in GBIF and other world databases as incorrect. It can be concluded that $S$. baldshuanica is a local endemic species only of Tajikistan.

The most recent herbarium specimens

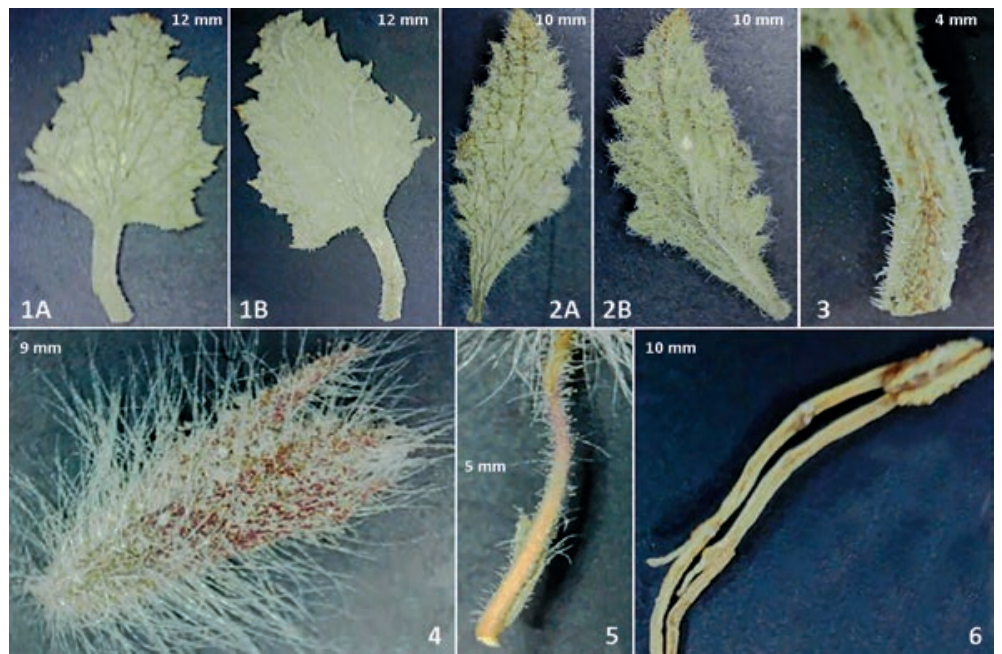

Figure 2 Morphology of Salvia baldshuanica Lipsky. Leaves: adaxial (1A, 2A) and abaxial (1B, 2B) sides; petiole (3); calyx (4); pedicel with the bracts (5); pair of stamens (6). The length of the structures in millimeters is presented

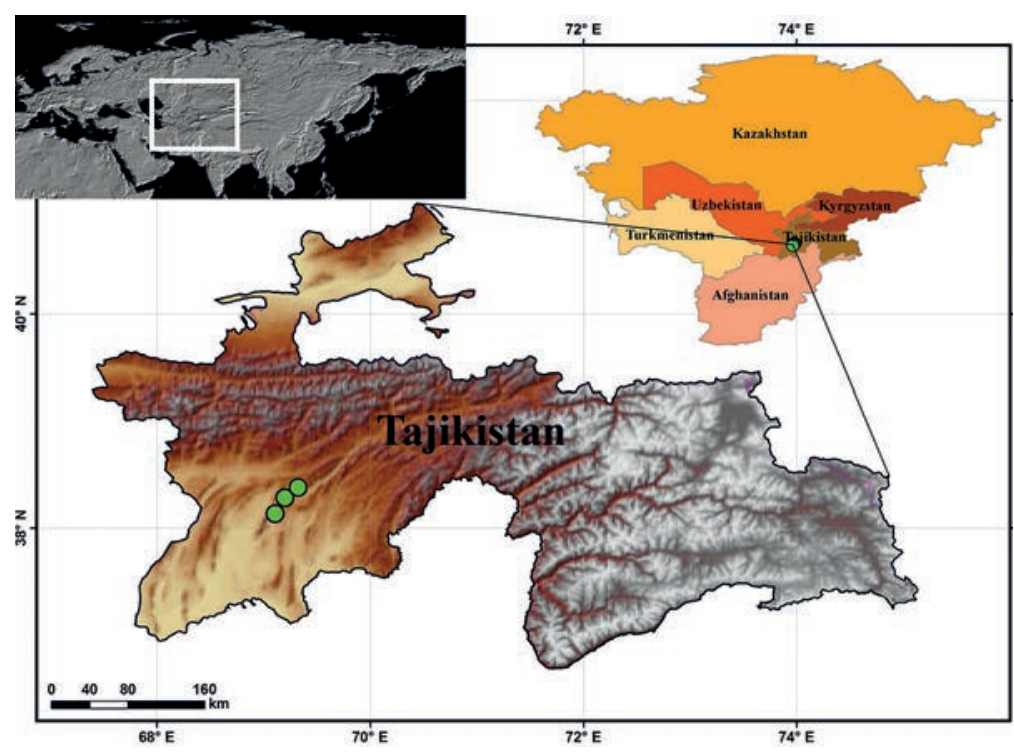

Figure 3 Distribution of Salvia baldshuanica Lipsky according to the revision of the TAD, LE, TASH herbaria of $S$. baldshuanica available in the GBIF and reflected in other world plant databases were collected more than 130 years ago; later collections are not taken into account. This was the reason to consider this species extinct with a high degree of probability (Humphreys et al. 2019). However, the species was found again almost 55 years after Regel's collection at the Sanglok Ridge near the Mansev village by M. Pryakhin. The last known collection of $S$. baldshuanica was made in 1979 by R. Kamelin and A. Makhmedov at the Sarsaryak ridge. Since no new finds of the species have been reported over the past 40 years, its possible extinction is eminent. However, this can only be confirmed or refuted by special efforts to find this species. This is a difficult task, taking into account the limited accessibility of this area and the rarity of the species.

According to the results of chorological analysis of $S$. baldshuanica distribution in Middle within Tajikistan. All known localities of the species are confined to the Sarsaryak ridge and Sanglok mountains (Fig. 3), which stretch along the left bank in the middle course of the Vakhsh River. The distance between the extreme locations based on topographic mapping of localities does not exceed $35 \mathrm{~km}$.

Habitats and phenology. Salvia baldshuanica inhabits gypsum rocks in the middle mountain belt (Makhmedov 1987). According to Kudryashev (1937), S. baldshuanica usually grows with Allium gypsaceum Popov \& Vved., Thesium gontscharovii Bobrov and Onobrychis gypsacea nomen invalidum. Kamelin and Makhmedov found a small isolated population of about 20 plants growing on gypsum rocks at an altitude of Asia it is a local endemic of the Western Pamir 
$1400 \mathrm{~m}$ above sea level (Makhmedov 1979), whereas Zhogoleva \& Kochkareva (1986) mentioned that this species can be found at altitudes of 1500-1800 m above sea level, and Rahimi et al. (2017) indicated a different altitude of 750-900 m above sea level.

The plants of $S$. baldshuanica flower from May to June and fruits set from June to July.

Etymology: The many herbarium specimens were collected as a result of research carried out by Albert Regel in the region of Baldschuan (Boldzhuan) in 1882-1883. The name of this region later became the basis for the designation of many species. The name of this Salvia species is given after the Baldschuan region by Lipsky (1900).

\section{ACKNOWLEDGEMENTS}

This study was supported by the "Taxonomic revision of polymorphic plant families of the flora of Uzbekistan (FZ-20200929321)" and was carried out within the framework of the State Assignment of the Central Siberian Botanical Garden SB RAS № AAAAA211210112900245. We are grateful to Mariya Sheludyakova (Herbarium of the Komarov Botanical Institute, LE, Saint-Petersburg, Russia) for all useful assistance. We also thank Veronique And ro (Herbarium of the Muséum Nationale d'Histoire Naturelle, MNHN, Paris, France) for providing images of the type material on their website, and Prof. Furkat Khassanov (National Herbarium of Uzbekistan, TASH, Tashkent, Uzbekistan) for valuable comments and suggestions. We express our thanks to T.C.H. Cole for English language editing and valuable comments. We are especially thankful to anonymous reviewers for valuable critical comments on the manuscript.

\section{LITERATURE CITED}

Baikova, E.V. 2006. Genus Salvia: morphiology, evolution, prospects of cultivation. Nauka, Novosibirsk, 248 pp. (in Russian). [Байкова Е.В. 2006. Род шалфей: морфология, эвоАюция, перспективы интродукции. Новосибирск: Наука, 248 с.].

Bobokalonov, K.A., V.A. Cheryomushkina \& M.T. Boboev 2020. Ontomorphogenesis and life form of endemic the Pamiro-Alai Ziziphora interrupts Juz. (Lamiaceae). BIO Web of Conferences 24:00012.

Borodin, A.M., A.G. Bannikov, V.E. Sokolov et al. (eds.) 1984. Red book of the USSR: Rare and vulnerable species of animals and plants, vol. 2. Lesnaya promyshlennost, Moscow, 480 pp. (in Russian). [Красная книга СССР: Редкие и находящиеся поА угрозой исчезновения виды животных и растений / Под реА. А.М. Бородина, А.Г. Банникова, В.Е. Соколова и Ар. Москва: Аесная промышменность, 1984. Т. 2. 480 с.].

Cheryomushkina, V.A., A.Yu. Astashenkov \& D.S. Saidov 2020. Parallelism in the development of life forms of species of the genus Kudrjaschevia (Lamiaceae): ontogenes and architectural analysis. Contemporary problems of ecology 13(3):257-265.

COL. 2021. Catalogue of Life. Available from: https://www. catalogueoflife.org. Last accessed 18.08.2021.

Davlatov, S.Kh. \& E.V. Baikova 2011. Altitudinal limits of Berberis L. in Tajikistan. Contemporary Problems of Ecology 4(2):164-166.

GBIF. 2021. The Global Biodiversity Information Facility. Available from: https://www.gbif.org. Last accessed
18.08.2021

Humphreys, A.M., R. Govaerts, S.Z. Ficinski, E. Nic Lughadha \& M.S. Vorontsova 2019. Global dataset shows geography and life form predict modern plant extinction and rediscovery. Nature Ecology \& Evolution 3(7):1043-1047.

IPNI. 2021. International Plant Names Index. Available from: https://www.ipni.org. Last accessed 18.08.2021.

JSTOR. 2021. Global Plants. Available from: https://plants. jstor.org. Last accessed 18.08.2021.

Khassanov, F.O. et al. 2015. Conspectus Florae Asiae Mediae, vol. 11. Izdatel'stvo "Fan" AS RUz, Tashkent, 456 pp. (in Russian). [Хасанов Ф.О. 2015. Определитель растений Средней Азии (критический конспект флоры). Ташкент: ИзА-во “Фан” АН РУ. Т. 11. 456 с.].

Kudryashev, S.N. 1937. Materials for the study of sage Central Asia. In: Trudy sek.tora rastitel'nyh resursov Komiteta nauk UzSSR, vol. 3, pp. 1-35 (in Russian). [Куаряшев C.Н. 1937. Материалы к изучению шалфеев СреАней Азии // Труды сектора растительных ресурсов Комитета наук У ССР. Вып. 3. С. 1-35].

Lipsky, V.I. 1900. Contributio ad floram Asiae Meridiae. Acta Horti Petropolitani 18(1):1-146. (in Russian with Latin diagnoses). [Аипский В.И. 1900. Материалы Аля фморы Средней Азии / / Труды Императорского Санкт-Петербургского ботанического сада. Т. 18, вып. 1. С. 1-146].

Lipsky, V.I. 1905. Pars III. Collectiones botanicae Asiae Mediae. In: Flora Asiae Mediae seu Turkestaniae Rossicae inclusis chanatis Buchara et Chiwa, pp. 338-841, Gerold, SaintPetersburg (in Russian). [Аипский В.И. 1905. Часть. III. Ботанические комлекции из Средней Азии // Фмора Средней Азии, т.е. Русского Туркестана и ханств Бухары и Хивы. Санкт-Петербург: ГерольА. С. 338-841].

Makhmedov, A.M. 1979. New record of Salvia badshuanica Lipsky. Doklady Akademii nank UzSSR 10:83-84 (in Russian). [Махмедов A.M. 1979. Новое местонахождение Salvia badshuanica Lipsky // Аоклады АН УзССР. № 10. C. 83-84].

Makhmedov, A.M. 1980. About the position of Salvia badshuanica Lipsky in the genus system. Uzbekskii biologicheskii zhurnal 5:74-75 (in Russian). [Махмедов A.M. 1980. O положении Salvia badshuanica Lipsky в системе рода // Узбекский биологический журнац. № 5. С. 74-75].

Makhmedov, A.M. 1984. Sage of Middle Asia and Karakhstan (taxonomy, geography, and rational use). Izdatel'stvo "Fan" UzSSR, Tashkent, 112 pp. (in Russian). [Махмедов A.M. 1984. Шалфеи Средней Азии и Казахстана (систематика, география и рациональное использование). Ташкент: ИзА-во “Фан” У

Makhmedov A.M. 1987. Salvia L. In: Conspectus Florae Asiae Mediae, vol. 9 (T.A. Adylov, ed.), pp. 138-150. Izdatel'stvo "Fan" UzSSR, Tashkent (in Russian). ПМахмедов A.M. 1987. Salvia L. // Определитель растений Средней Азии. Конспект флоры. Т. 9 / под ред. Т.А. ААылова. Ташкент: ИзА-во “Фан” У ССР. С. 138-150].

MNHN \& Chagnoux, S. 2021. The vascularplants collection (P) at the Herbarium of the Muséum national d'Histoire Naturelle (MNHNParis). Version 69.230. MNHN - Museum national d'Histoire naturelle. Occurrence dataset https://doi.org/10.15468/ nc6rxy accessed via GBIF.org on 13.10.2021.

Orrell, T. \& Informatics Office 2021. NMNH Extant Specimen Records. Version 1.46. National Museum of Natural History, Smithsonian Institution. Occurrence dataset https://doi. org/10.15468/hnhrg3 accessed via GBIF.org on 13.10.2021.

Ovchinnikova, S.V, D.M. Tajetdinova, O.A. Turdiboev \& K.S. Tojibaev 2020. Type specimens of names of taxa of 
Heliotropiaceae and Boraginaceae kept in the National Herbarium of the Uzbekistan of Institute of Botany of Academy of Sciences of the Republic of Uzbekistan (TASH). Turczaninowia 23(3):36-57 (in Russian with English summary). ГОвчинникова С.В., Тажетдинова А.М., Турдибоев О.А., Тожибаев К.Ш. 2020. Типовые образцы названий таксонов семейств Heliotropiaceae и Boraginaceae, хранящиеся в Национальном гербарии Узбекистана Института ботаники Академии наук Республики Узбекистан (TASH) // Turczaninowia. Т. 23, № 3. С. 36-57].

Pobedimova, E.G. 1954. Salvia L. In: Flora of the USSR = Flora URSS, vol. 21 (B.K. Schischkin, ed.), pp. 244-363, Izdatel'stvo Akademii nauk SSSR, Moscow \& Leningrad (in Russian). ППобедимова Е.Г. 1954. Род Salvia L. // ФАора СССР. Т. 21 / поА реА. Б.К. Шишкина. М., $\Lambda$. : Иза-во АН СССР. С. 244-363].

Pobedimova, E.G. 1977. Salvia L. In: Flora of the U.S.S.R., vol. 21 (B.K. Schischkin, ed.), pp. 178-260, Keter Publishing House, Jerusalem (translated from Russian).

POWO. 2021. Plants of the World Online. Facilitated by the Royal Botanic Gardens, Kew. Available from: http: / www. plantsoftheworldonline.org. Last accessed 18.08.2021.

Rahimi, F., K. Ibodzoda, I. Abdusalyamov et al. 2017. The Red Data Book of the Republic of Tajikistan, edition 2, vol. 1. Flora. Dushanbe, 590 pp. (in Tajik).

Seregin, A. 2021. Moscow University Herbarium (MW). Version 1.201. Lomonosov Moscow State University. Occurrence dataset https://doi.org/10.15468/cpnhcc accessed via GBIF.org on 13.10.2021.

Thiers, B. 2016. Index herbariorum: A global directory of public herbaria and associated staff. New York Botanical Garden,
Bronx, NY. Available from: http://sweetgum.nybg.org/ ih/. Last accessed 29.07.2016.

Talovskaya, E.B. 2020. Modification of architecture of dwarf subshrub Thymus seravschanicus (Lamiaceae) in the Republic of Tajikistan. Contemporary Problems of Ecology 13(3):266-273.

Turland, N.J., J.H. Wiersema, F.R. Barrie, W. Greuter, D.L. Hawksworth, P.S. Herendeen, S. Knapp, W.-H Kusber, D.-Z. Li, K. Marhold, T.W. May, J. McNeill, A.M. Monro, J. Prado, M.J. Price \& G.F. Smith (eds) 2018. International Code of Nomenclature for algae, fungi, and plants (Shenzhen Code) adopted by the Nineteenth International Botanical Congress Shenzhen, China, July 2017. Regnum Vegetabile 159. Koeltz Botanical Books, Glashütten, 254 pp.

Zhogoleva, E.P. \& T.F. Kochkareva 1986. Salvia L. In: Flora of Tajikistan, vol. 8 (T.F. Kochkareva, ed.), pp. 241-257, Nauka, Leningrad (in Russian). [Жоголева Е.П., Кочкарева Т.Ф. 1986. Salvia L. // ФАора Таджикской ССР / под реА. Т.Ф. Кочкаревой. А.: Наука. Т. 8. С. 241-257].

Virtual Herbaria. 2021. Available from: https://herbarium. univie.ac.at/database/collections.htm. Last accessed 18.08.2021.

WCSP. 2021. World Checklist of Selected Plant Families. Facilitated by the Royal Botanic Gardens, Kew. Available from: https://wcsp.science.kew.org. Last accessed 18.08.2021.

WCVP. 2021. World Checklist of V ascular Plants. Facilitated by the Royal Botanic Gardens, Kew. Available from: https:// wcvp.science.kew.org. Last accessed 18.08.2021. 